\title{
Pandemic Nationalism
}

\author{
Harris Mylonas ${ }^{1}$ and Ned Whalley \\ ${ }^{1}$ George Washington University, Washington DC, USA \\ Corresponding author: Harris Mylonas, email: harris.mylonas@gmail.com
}

\begin{abstract}
"Because of our inability to solve the problem of international organization, it has actually contributed to the dangers which threaten peace and the very existence of mankind." - Albert Einstein, Open Letter to the General Assembly of the United Nations (October 1947)
\end{abstract}

\section{Introduction}

It has been two years since a novel coronavirus broke out of China and spread rapidly across the world, bringing untold suffering to its victims and those affected by the economic collapse and social isolation that has followed. Official figures have put the death toll as high as 5.2 million to date, though some analysts estimate the true number to be far higher, over 15 million (Economist 2021). The pandemic is the first of its kind in a century, and the lack of precedent or predetermined plans of action has provoked a dizzying array of state responses: closed borders, testing regimes, national lockdowns, stringent school protocols, and ultimately mass vaccination programs. In concert with the disease, government measures have given rise to new behaviors among populations forced to negotiate a newly asocial existence. The compounding effects of the massive death toll, economic contraction, supply chain disruption, lost years of education, and the collective alienation of enforced isolation will not become fully apparent for some time.

It is hard to predict the weather from inside the storm, but the pandemic has laid bare a number of features of contemporary societies and their mobilizing ideologies. While state populations have been mobilized for many causes and on the basis of many principles - religious, partisan, economic, universalist, and so forth - most states today legitimate their authority through the ideology of nationalism, on behalf of an imagined community aspiring to sovereignty over a particular territory coterminous with its political borders. During the pandemic, a nationalist human calculus has prevailed. Solidarity has been extended to co-nationals but has been less forthcoming beyond that point. All states have responded by turning inward. Border closures have been at the heart of mitigation efforts from the very beginning, and lockdowns legitimated and often enforced through national and patriotic discourses. It was common to hear arguments like, "our ancestors fought in wars to defend the nation, you can do it by lying on your couch," when the first lockdowns were introduced. Nationalism has played an important role in legitimating restrictive measures and motivating millions of people to comply with them. In this sense, nationalism has helped governments to overcome a collective action problem at the state level. Imagine the converse, if citizens around the world had behaved solely based on their narrowly defined self-interests. Even state elites that do not primarily legitimate their authority through nationalism, such as communist regimes or theocracies, have behaved in an explicitly nationfirst manner. A pattern worth exploring is whether contested constitutive stories impede nationalism's coalescing force in the fight against the pandemic - as many of the contributions to this issue suggest while in states with uncontested constitutive stories it proves a more useful tool.

But while nationalism has unquestionably helped overcome collective action problems within state borders, it has undermined them at the global scale. The most clear example has been the abject 
failure of international organizations to coordinate an appropriate response. This has particularly affected developing countries. Despite or because of its ubiquity, the impact of the pandemic has not prompted a globally united effort. The Covid-19 Vaccines Global Access (COVAX) program, an international initiative for the equitable distribution of vaccines, has faced chronic shortages and had limited impact: rich countries, irrespective of the ideological orientation of their government, have not contributed nearly enough, instead focusing on meeting domestic demand. Epidemiologists have attributed the emergence of variants of concern, such as Delta and Omicron, to low vaccination rates in developing countries, a direct consequence of the nation-first approach that has been the dominant response across most states in the world, but most importantly those that have vaccine-abundance. While it is true that even countries with a surplus of vaccines cannot vaccinate their entire populations, and that vaccinated people can also spread the virus, it is also clear that unvaccinated populations are much more likely to pass on the virus and thus generate more mutations. The more of the latter occur, the greater the chance of variants of concern to emerge.

The hoarding of vaccines and the phenomenon of so-called vaccine nationalism-the politicized distribution of vaccines to favored countries-speak to the weakness of international institutions in bringing about effective collective action. The World Health Organization has been hamstrung in its coordination efforts. The opening of a vaccine hub in Germany in September of 2021 has been overshadowed by its inability to ascertain the cause of the outbreak, an effort being hampered by the Chinese government. Even in the European Union, the diverse array of responses, including travel bans and the closure of internal borders, has emphasized the conditional nature of interstate relationships.

The general weakness of supranational institutions is well documented, but the pandemic has demonstrated that even new, explicitly global challenges trigger a familiar pattern of nation-first response. The prospects of successfully combatting similarly dispersed challenges, such as climate change, should probably be downgraded, and conceptualizing international entities as alliances or consociations, rather than fora, is likely premature. The United Nations was, after all, originally designed to protect states from each other. Relatedly, governments, companies, and consumers have been reminded of the precariousness of globalized supply chains in times of crisis. Our ability to cooperate at the global level remains poor.

We are left then, with further evidence of the primacy of the national state and its organizing ideology, nationalism, both on full display in a period marked by death, impoverishment, and economic uncertainty. The range of state responses may offer a clearer lens through which to examine different contexts and ideologies and their internal and external manifestations. In many respects, the pandemic has operated most convincingly as an intensifier of existing trends: states have largely confronted their challenges in ways that reflect their respective social contracts with their populations and, tellingly, through narratives celebrating the superiority of their response vis-à-vis other states. Vaccination rates and death tolls are cataloged and compared, imbued with national and regional pride and discomfort. Political rhetoric has often been characterized by overwhelmingly nationalist overtones, likening the fight against the virus to a war.

Governments have also used nationalist tropes to mobilize their populations into cooperative behavior, to accept the economic and social costs of shutdowns and isolation, and to support the systems and measures being implemented to combat the spread of the virus, including unprecedented levels of state spending. These, in turn, have generated debate and backlash, as, around the world, the expanded scope and role of the state are negotiated and renegotiated. Reactions to these measures have formed potent new social cleavages, often overlapping with existing ideological, racial, or class-based lines. Pandemic nationalism has undermined a globalized response, but internal social cohesion also faced challenges across states through various forms of politicized backlash. Extremist political ideologies and fringe conspiracies have been gifted a new and potent subject of discourse. In some democracies, electoral incentives have led opposition parties to represent and empower those resisting health mandates and other inconvenient measures. In others, opposition parties have criticized governments for not doing enough to fight the pandemic. 
In turn, polarization has increased as a result of the frustration growing within the population abiding by health mandates and the anger of those that oppose them.

What is it about nationalist narratives and tropes, emphasizing the primacy of national solidarity, that have made them so suitable for instrumentalization during the pandemic? What does the pandemic reveal about perennial moral dilemmas between individual and societal interest, as well as the national and the global interest? This special issue of Nationalities Papers includes work by numerous scholars casting light on the uses and abuses of the ideology of nationalism in government and opposition responses to the pandemic. Its empirical scope is largely focused on democratic nation-states, but the arguments have relevance for the study of other groups, such as migrant and refugee populations, and other regimes, authoritarian or theocratic, especially when it comes to the intersection of disease and political power in these contexts. It will take years before the myriad effects of the pandemic can be properly measured and understood-the owl of Minerva flies only at dusk-but the human cost and reshaping of domestic and professional life and political discourse have been so acute that there is much that can already be gleaned. This special issue includes some of the first empirical research on the electoral effects of the pandemic in democratic settings, along with historical and analytical mapping of the enormous breadth of the pandemic's political and social impact and the concomitant variation in responses around the world.

\section{Pandemic Fear and Exclusionary Nationalism}

To catalogue the specific effects of the pandemic on nationalism and nationalist discourses, it is necessary to assess the social and political character of the world it entered. Harris Mylonas and Maya Tudor (2021) have identified the increasingly exclusionary forms of nationalism ascendant over the past decade as an important feature of the contemporary global order into which the pandemic arose. Tribalism, othering, and fearmongering have remained a disturbing and salient part of political discourse. And while the duration of the pandemic has obscured this aspect of its impact in some quarters, the virus continues to instill fear.

As Florian Bieber notes in this special issue, "Fear of illness or the hardship associated with government responses and the economic crisis are real and tangible for a substantial share of the global population. Fear is also a potent and dangerous motivator in political choices," (Bieber 2022). The coming of the virus brought a new element of fear and uncertainty into an environment where these emotions were already being instrumentalized in antisystemic discourses. Examining fear as both a push and pull factor is useful for understanding both the increasing populism of the last decade and the shared positions of several populist-nationalist movements, such as an opposition to international cooperation and free trade. But examining the effects of fear also illuminates the seemingly unpredictable stances of these movements with regard to international conflict and their penchant for revisionist, self-serving foreign policy. Such analyses can also help identify corresponding ideologies that have accompanied the spread of the virus.

These positions have found expression in the pandemic, from the British deciding not to join a European scheme to share medical equipment, to the Trump administration's choice to leave the World Health Organization and refusal to participate in the COVAX initiative. If fear is a primary underwriter of nationalist retrenchment and populist discourse, then examining the fear generated by the pandemic is essential for understanding its political impact. And while fear was the dominant emotion in the early stages of the pandemic, anger and frustration - of or against governments, antivaxxers, and anti-lockdown groups - have been close seconds in later stages.

Among the contributors to this special issue, Erin Jenne (2022) identifies two ideal typical sovereign imageries: liberal nationalist and ethnopopulist. Liberal nationalist responses are more likely to conform with policies advocated by the World Health Organization and the mainstream scientific community, and have sought to balance prescribed lockdowns and mask mandates with protection of free trade and commerce: "In the context of disease pandemics, liberal nationalism 
prescribes the broadest possible defense of diverse segments of the nation through robust border control as well as technocratic science-based methods to control the virus at the local level," (Jenne 2022). Ethnopopulist nationalist responses are typical of, among others, the Trump administration, particularly in its framing of the virus as a part of the larger threat posed by China and its painting of the political opposition as part of this same specter. The degree of exclusion is bizarre in some cases: Jenne notes that the Trump administration went as far as favoring Republican states in the federal distribution of medical equipment. While the crisis was inevitably going to be politicized domestically, the hallmark of the ethnopopulist nationalist response is the instrumentalization of virus policies themselves as exclusionary nationalist markers.

This raises the specter of a spiraling exclusionary nationalism, where nation-state-centric policies frustrate the efforts and undermine the legitimacy of international liberal institutions attempting to solve a global collective action problem. The resultant inadequacy of their response then improves the relative appeal of exclusionary nationalist measures as a viable alternative. Writing at the outset of the pandemic, Bieber identified exclusionary nationalism as particularly susceptible to the fear and authoritarianism that have accompanied the spread of the virus and efforts to contain it. As noted by Jakub Wondreys and Cas Mudde (2022) in this issue, the far right has been happy to use the pandemic to further existing narratives, whether against immigration or the rising relative power of China. The pandemic has provided the far right with a new tool for infiltrating mainstream discourses and the public sphere, and the longer it rages, the more fodder it might provide to isolationism and nativism, even if proponents of these tenets are not immune to public dissatisfaction themselves. Bieber (2022) locates similar dangers in the rise of authoritarian tendencies in Western governments. The pandemic has provided a pretext for state overreach into domestic life, stricter control over immigration and borders, and restrictions on the right to congregate, in both democratic and non-democratic regimes. The willful ceding of such powers is nearly unprecedented and likely dangerous: "government responses to the pandemic risk turning fragile democracies into competitive authoritarian regimes. Such competitive authoritarian regimes might initially rely on the pandemic to justify repressive policies, but they are likely to turn to exclusionary nationalism as a key legitimizing ideology in order to sustain power," (Bieber 2022). The legitimation of such regimes is underpinned by the fear generated by the pandemic, but also in the decade of crises that proceeded it: "The economic uncertainty after 2008, the narrative of migration as a threat, and now the pandemic all have contributed to a social environment of uncertainty and fear. In addition to the psychological consequences of collective anxiety, the political and social outcome is more likely to strengthen exclusionary nationalism" (Bieber 2022).

The result of such uncertainty has been damaging. As Prerna Singh (2022) notes in her contribution, "the preexisting plague of right-wing, populist, exclusionary nationalism made the pandemic more dangerous than it might otherwise have been.” And the longer it continues, the more dangerous the consequences may become: "increased concern about disease is in turn likely to further breed anxiety about those seen as outsiders, continuing to push forward a toxic juggernaut of fear, divisions, and exclusions around contagion," (Singh 2022). The pandemic is testing the durability of contemporary social and political liberalism and their ability to withstand the allure of exclusionary mobilization. "In as much as its intersection with the ascendancy of exclusionary nationalist regimes across the world has worsened the us-them divisions that might otherwise have been wrought by COVID-19, the pandemic itself has added fuel to the raging fire of exclusionary nationalism," (Singh 2022).

But as Singh notes, nationalist mobilization operates in many frameworks. It has also been a marshalling ideology in the fight against the pandemic. Singh cites the framing of vaccination as a patriotic duty in China, the so-called "peoples" war" against the virus promoted by the communist party in Vietnam, and the rise in volunteering in Europe. Some of the most visible aspects of the pandemic have been the re-introduction of nationalist discourses into everyday life, and the selfconscious practice of nationalist behavior by ordinary citizenry. 


\section{Pandemic Nationalism and Right-Wing Politics}

Despite the effusion of racist and/or exclusionary nationalist rhetoric it has provoked, the pandemic has not mapped tidily onto existing political spectrums, and the incompetence of incumbent administrations has not always been punished. President Trump's refusal to wear a mask and promotion of home remedies drew condemnation and cost lives, but it remains unclear if his mishandling of the crisis or the economic downturn that accompanied it were major contributors to the outcome of the 2020 US presidential election. In their contribution to this issue, Wondreys and Mudde (2022) look at far-right responses to the pandemic, noting that the far right itself is both more heterogenous and more mainstream than ever before. In Europe, far-right parties have entered ruling coalitions, and as far afield as Brazil and India, right-wing populism is a dominant force in contemporary politics. But right-wing politics is far from monolithic, and its discourses on the pandemic have exhibited substantial variation.

The initial minimization of the threat, espoused by US President Donald Trump, Brazilian President Jair Bolsonaro, and British Prime Minister Boris Johnson was not a uniform response on the right. Wondreys and Mudde (2022) note that in Italy, hit hard and early by the virus, the League party perceived it as a major threat. Indian Prime Minister Narendra Modi, noted for his espousal of Hindu nationalism, has been vociferous in his support for social distancing and vaccination. The exlcusionary nationalism that the pandemic generated has also taken different forms. While the United States has a substantial Asian American population and was in the midst of a major trade dispute with China, European nativism has recently been focused elsewhere, on immigration. The anti-China narratives popular in the United States had less traction in places like Italy, where they were less operative politically. In Hungary, Prime Minister Viktor Orbán's party praised the Chinese response.

Analyzing preliminary data on cases and deaths as well as electoral results, Wondreys and Mudde find that while far-right parties utilized nativist narratives that constitute part of their ideological core, their approach to policy was strongly affected by whether they were in or out of government. Lockdowns and mask policies were variously supported or condemned based on whether they could be politically instrumentalized. The uncertainty over how to combat the spread of the virus left room for both far-right support of greater authoritarian measures and populist demonstrations against them.

We must also be careful in drawing conclusions about the relative ineptitude of right-wing governments in handling such crises. While Trump's promotion of bogus treatments seemed emblematic of his administration's poor response, in Europe at least, Wondreys and Mudde found little initial difference in the effectiveness of governments along the political spectrum. They caution against prognostications on the effects of the pandemic on the right as whole, noting the general durability of European political systems against exogenous shocks. Despite the ubiquity of the pandemic in far-right discourses, it is too early to fully assess its political impact.

\section{Nationalist Conspiracies}

Pandemic nationalism has not been limited to the political sphere. Fear was quickly manifest in the profusion of conspiracy theories that spread in concert with the virus. The novelty and scale of the pandemic lend themselves to proportionality bias-the assumption that highly consequential events must have commensurately significant causes. The propensity for such bias is a primary driver of conspiracy theories, and the pandemic has produced scores. The unclear origins of the coronavirus have provoked intense speculation, as has the response. The Chinese government initially covered up the existence of the virus, silenced whistleblowers, and began a campaign to blame other parties, in particular, the United States. The World Health Organization, hampered by the Chinese government's limited cooperation, has so far failed to conclusively identify the origin of the virus, precipitating a further round of speculation. But the prominence of conspiracies with nationalist content-including scapegoating and state propaganda-reveals much 
about current domestic appetites for xenophobia and its utility for a wide range of political actors, both in government and opposition.

Tracing the long history of conspiratorial narratives surrounding disease, Siniša Malešević's (2022) contribution to this issue notes that such conspiracies have historically blamed specific groups for pestilences, but that the makeup and characterizations of these groups has changed with the salience of new forms of identity. During the plague of Cyprian, Christian clergy blamed Jews and pagans for the disease. A thousand years later, as the Black Death ravaged Europe, Christian religious groups led a mass persecution of Jews across Europe and extended their wrath to include Muslims, Mongols, lepers, and heretics.

But with the rise of nationalist structures and ideologies came overtly nationalist conspiracies. While virulent antisemitism and xenophobia remained, these were now joined by characterizations of an explicitly nationally defined Other. Such narratives were politicized from the outset; the French Revolution swirled in conspiracies real and imagined, and a century of jingoistic competition between the European powers ossified an oppositional nationalist framework of public discourse and conspiracy, one that contributed to the First World War. The pandemic that struck at the end of that conflict became known in the West as the Spanish Flu, but it held numerous monikers suggesting various foreign origins_among them "Russian plague," "American disease," "Chinese sickness"-along with a host of conspiracies accusing foreign nationals of spreading it intentionally (Malešević 2022).

Naming a disease after its presumed source reveals more than a geographic understanding of transmission. The identification of a disease as foreign maps onto existing nationalist frameworks and identifies a responsible party. These paradigms have again become familiar. In March 2020, US President Trump was famously photographed having struck the word "coronavirus" from a speech, replacing it with "Chinese virus" (Bieber 2022). It appeared to be his only edit. The change served no purpose except as an implicit apportionment of blame. It is no great leap from fault to intent and from there into the world of conspiracy.

The coronavirus has thus predictably birthed not just bizarre conspiracies involving telecommunications towers, but ones assigning blame to various countries, in particular China, the United States, Russia, and Israel (Malešević 2022). Their propagation has been both a bottom-up and a topdown phenomenon. Malešević notes importantly that the proliferation of the internet and social media allow for fully global conspiracy theories in terms of consumption, but that these often reinscribe the nationalist frameworks of their progenitors. Governments were quick to see the utility of blaming a national emergency-and its economic and human cost-on a foreign competitor. Members of the Trump administration exercised every opportunity to emphasize the foreign nature of the virus, and an unsubstantiated claim that it originated in a Chinese lab. The Chinese government went further, with a coordinated propaganda campaign to shift blame to the United States, or in some narratives, Italy, at one point suggesting that the virus leaked from a military installation in Maryland (Ramzy and Chien (2021).

None of this should be surprising. As Malešević (2022) points out, “Despite being presented as a challenge to 'normal' perceptions of reality, conspiracy theories reinforce embedded nationalist idioms and practices. They draw upon existing nation-centric imagery and push nationalist messages to their logical conclusions." But while the tropes are familiar, the world has not experienced a pandemic in generations. The relationships of states to one other is modulated by nationalist discourse, but so too is the mediation taking place between states and their constituents. The logical conclusions of conspiratorial narratives are uncountable, but they include violence and conflict.

\section{Everyday Pandemic Nationalism}

The uncertainty and fear created by the pandemic have driven people to embrace familiar and historical paradigms, with nationalism foremost among them. In their contribution to this issue, 
Paul Goode, David Stroup, and Elizaveta Gaufman note that "the perceived relationship between structure and routine in the process of meaning-making is inverted in unsettled times: rather than interpreting the meaning of social practices in relation to social structure, social practices seek to affix national meanings to social structures that are in flux," (2022). In effect, we are witnessing an increase in consciously nationalist behavior from below. It is not just governments, but "ordinary people [who] seek national solutions to global problems," (Goode, Stroup, and Gaufman 2022).

Goode, Stroup, and Gaufman note the performative nature of everyday nationalism that has become common over the past two years. Early in the pandemic, citizens of the United Kingdom engaged in nightly communal applause for workers of the National Health Service (NHS). The institution already held a special place in British politics as the most popular arm of the welfare state, but the pandemic has thrust it further into the spotlight. Ad hoc window displays in support of the NHS are now common, many done by children. The government caught on: mask wearing and travel restrictions in the United Kingdom were deliberately framed as ways of protecting the institution rather than as an expansion of state power.

The domestic performance of nationalist narratives, both in-group solidarity and out-group exclusion, have taken more overt forms during the pandemic, as have debates and demonstrations about the nature of the state. Goode, Stroup, and Gaufman cite the politicization of mask wearing and protests against lockdowns as negotiations of the public sphere: "In moments where the structure of social control and the status quo fracture, the prospect of loss leads ordinary people to seek more risk in attempts to enact change that minimize harm," (2022; see also Snow et al. 1998). The proliferation of protests against government restrictions around the world could thus be explained in part by the turbulent political and socioeconomic circumstances the pandemic has created.

Such debates invariably broach questions of identity. "As ordinary people attempt to find ontological security in their appeals to the community of the nation, ideas concerning what is normal and who is included in normality become normative assertions of the nation as these participants believe it ought to be, or should have been if not for the intervening crisis" (Goode, Stroup, and Gaufman 2022). It is possible that such a renegotiation of national inclusion informed or influenced the confluence of factors driving the Black Lives Matter protests across the United States and other countries following the murder of George Floyd. It is certain that exclusionary forms of nationalism provoked violence against and harassment of Asians and Asian Americans in the United States, prompted by the virus' initial appearance in China and the accompanying antiChinese rhetoric promulgated by right-wing politicians and media. Ultimately, it is people who pay a physical price for identity consumption in the service of ontological security.

\section{Border Closures and Secessionist Movements}

This reification of nationalist narratives has been particularly visible in the renewed salience of borders. Hynek Böhm's contribution to this special issue studies the depth and limits of pandemicinduced border closures in the highly integrated town of Cieszyn-Český Těšín, which straddles the Czech-Polish frontier and exhibits substantial cross-border traffic in people and commerce. Border controls undermined this status quo, causing enormous social and economic disruption. Efforts from regional governments to prolong the closures ultimately led to outrage and protests from locals. "The local politicians jointly underlined the European dimension of the life in the divided town and criticized the representatives of the central governments of both countries," (Böhm 2022).

Cieszyn-Český Těšín possesses some unique features, as "it shares the common history, language barrier is minimal, the Polish minority in Czechia acts as a co-operation bridge, and there is an interesting offer of jobs on the Czech side of the border," (Böhm 2022). On both sides, anger over the border closures was aimed at capitals rather than neighboring peripheries. But the case is an illustrative one-fear of contagion has rent some of the most socially and legally integrated living spaces where an internationally recognized border lies between them. 
Jonathan Parker (2022) also focuses on challenges to state borders, arguing that the pandemic has fueled pre-existing secessionist movements. In Spain, the policy of the government was heavily criticized by secessionist parties in Catalonia, who called for stricter lockdowns, including the closure of Catalonia's borders (Parker 2022). The Flemish-Walloon division, which has frustrated efforts to form Belgian governments for decades, has seen its respective parties instrumentalize the pandemic, as Flemish nationalists have sought the regionalization of the provision of healthcare and proposed further devolution of power. In the United Kingdom, the Conservative government devolved pandemic policy from the outset, allowing its constituent nations, including Scotland, governed by the secessionist Scottish National Party, to design and enforce their own measures.

But while all these secessionist parties have utilized the pandemic and the platform it has provided to further their existing political priorities, Parker finds that the effect on support for secession and secessionist parties has been unpredictable. Secessionist movements in Spain and Belgium do not seem to have benefited, though support for the Scottish National Party measurably rose. Much of this has to do with context, with the pandemic offering a natural experiment in how different political environments yield different results in response to similar challenges. Nicola Sturgeon, first minister of Scotland and leader of the Scottish National Party since 2014, was widely praised for her demeanor and clarity in television addresses, while the response of Boris Johnson's government appeared erratic and ill-considered from the outset, when he had to walk back aspirations for rapid herd immunity. The fact that Sturgeon's government was allowed to dictate its own policies with regard to the pandemic allowed for direct comparison of action as well as discourse. Indeed, it is notable that whereas Catalan parties chose to "to aggressively pursue a nationalist narrative" (Parker 2022) the Scottish National Party refrained from such explicit agitation.

The pandemic provided a clear opportunity for the furtherance of secessionist movements and fragmentation, aided in part by the geographic restrictions of lockdowns and the renewed saliency of borders. Power struggles over pandemic policies have taken place along traditional cleavages: the center versus the periphery and central versus local government. Battles over city, state, and federal pandemic-related restrictions became common in US politics. But the political success of explicitly secessionist ventures has been far more mixed and remains unclear. The tension and competition between state and secessionist nationalisms and the costs and benefits of new and renewed borders are complex phenomena and context dependent.

\section{Conclusion}

The coronavirus pandemic and its fallout continue to surprise in terrible fashion. Countries such as Greece or Israel, which perplexed or impressed with low levels of infection during the first wave, have since fallen victim to its spread. Countries with early vaccination programs like the United States and United Kingdom are combatting healthcare crises at the time of writing. A shortage of vaccines in developing countries, resistance to vaccination programs, and the rise of new variants pose short- and long-term risks to every facet of human life. The pandemic remains a mortal threat and a constraint on human activity. In its midst, open displays of nationalism, projected both domestically and internationally, have been unmistakable. Have governments and their citizens retreated into familiar tropes because of uncertainty, or is the pandemic simply yet another reminder of the limits of cosmopolitanism?

The pandemic has reiterated the primacy of nationalism and state politics for the mobilization of human and economic resources. In the international sphere, in times of insecurity or scarcity, states do appear to act in their own narrowly defined self-interests. Publics demand this course of action, and governments, almost uniformly, rely on domestic sources of legitimation. It is in the nature of democratic regimes to orient themselves to their "demos," be it national or multi-national.

The failure of international organizations in the face of such a global threat reveals a classic collective action problem. Global investment in vaccination would generate enormously more 
productivity and revenue in the long run than such a project would cost, and might help limit the emergence of new variants. But as the benefits would not accrue directly to the underwriters, such efforts are pursued piecemeal, falling prey to more parochial, short-term political interests, attempts to buy influence or penetrate new markets. Public goods are always undersupplied. The hoarding of vaccines, supported by all types of political parties in established democracies, suggests it may provide a form of ontological security, or reflects a political fear of being outflanked by the right. Vaccine nationalism is little more than a collective admission that the provision of aid is political. When the Biden administration promised a million doses of the vaccine to Vietnam, the Chinese government promptly pledged to double it. Such assistance may serve as a measure of national prestige and global leadership in some quarters, but assistance to poorer and less strategically or economically important partners has been less forthcoming.

The virus has laid bare the degree of global disparity and the continued failure of the so-called international community to ameliorate it. Rich countries have acted on behalf of their citizens and poor countries have been left behind. International institutions such as the World Health Organization have been accused of incompetence, and aid regimes have been unable to meet overwhelming demand. The United States, the most economically and financially important country in the world, was slow to export its vaccines, sending one of the smallest percentages of its production abroad. The pandemic will recede first from states with the financial capability to mitigate it, and the result will likely be an intensification of the inequality between developed and developing countries.

We must wait to see if the virus drives global inequality further in the international arena, just as we must wait to see if the rising tide of populist nationalism draws fuel from the messy competition to reach the other side of the pandemic. External competitors may use internal cleavages over the politicization of vaccination and lockdowns to undermine the stability of their competitors. Internal competitors may continue to politically instrumentalize these issues to their benefit. The pandemic has presented unique challenges to all political systems, a concomitant degree of chaos, and opportunities for those waiting to take advantage. The mapping of such competition, and its interplay with existing nationalist ideologies, will dictate the post pandemic political order, with effects that will long outlast the virus. Pandemic nationalism is far from over.

Acknowledgments The authors would like to thank Florian Bieber, Hynek Bohm, Elizaveta Gaufman, Elizabeth Grasmeder, Paul Goode, Erin Jenne, Adam Lenton, Athena Leoussi, Siniša Malešević, Cas Mudde, Jonathan Parker, Anum Pasha, Dylan Royce, Prerna Singh, Katrina Swartz, David Stroup, and Jakub Wondreys for their enormous help and valuable contributions to this special issue, which they generously provided under difficult circumstances.

Disclosures. None.

\section{References}

Bieber, Florian. 2022. "Global Nationalism in Times of the COVID-19 Pandemic.” Nationalities Papers, 50 (1): 13-25.

Böhm, Hynek. 2022. "Challenges of Pandemic-Related Border Closures for Everyday Lives of Poles and Czechs in the Divided Town Cieszyn/Český Těšín: Integrated Functional Space or Re-emergence of Animosities?” Nationalities Papers, 50 (1): $130-144$.

Economist. 2021. “The Pandemic's True Death Toll.” October 27, 2021. https://www.economist.com/graphic-detail/coronavi rus-excess-deaths-estimates.

Goode, J. Paul, David R. Stroup, and Elizaveta Gaufman. 2022. "Everyday Nationalism in Unsettled Times: In Search of Normality during Pandemic." Nationalities Papers, 50 (1): 61-85.

Jenne, Erin. 2022. "Varieties of Nationalism in the Age of Covid." Nationalities Papers, 50 (1): 26-44.

Malešević, Siniša. 2022. "Imagined Communities and Imaginary Plots: Nationalisms, Conspiracies, and Pandemics in the Longue Durée." Nationalities Papers, 50 (1): 45-60.

Mylonas, Harris, and Maya Tudor. 2021. "Nationalism: What We Know and What We Still Need to Know." Annual Review of Political Science 24: 109-132.

Parker, Jonathan. 2022. “Europe's Secessionist Movements and Covid-19.” Nationalities Papers, 50 (1): 118-129.

Ramzy, Austin, and Amy Chang Chien. 2021. "Rejecting Covid Inquiry, China Peddles Conspiracy Theories Blaming the U.S.” New York Times. August 25. https://www.nytimes.com/2021/08/25/world/asia/china-coronavirus-covid-conspiracy-theory. html. 


\section{Harris Mylonas and Ned Whalley}

Singh, Prerna. 2022. "How Exclusionary Nationalism Has Made the World Socially Sicker from COVID-19." Nationalities Papers, 50 (1): 104-117.

Snow, David, Daniel Cress, Liam Downey, and Andrew Jones. 1998. "Disrupting the Quotidian: Reconceptualizing the Relationship between Breakdown and the Emergence of Collective Action.” Mobilization: An International Quarterly 3 (1): 1-22.

Wondreys, Jakub, and Cas Mudde. 2022. "Victims of the Pandemic? European Far-Right Parties and COVID-19." Nationalities Papers, 50 (1): 86-103.

Cite this article: Mylonas, H. and Whalley, N. 2022. Pandemic Nationalism. Nationalities Papers 50: 3-12, doi:10.1017/ nps.2021.105 